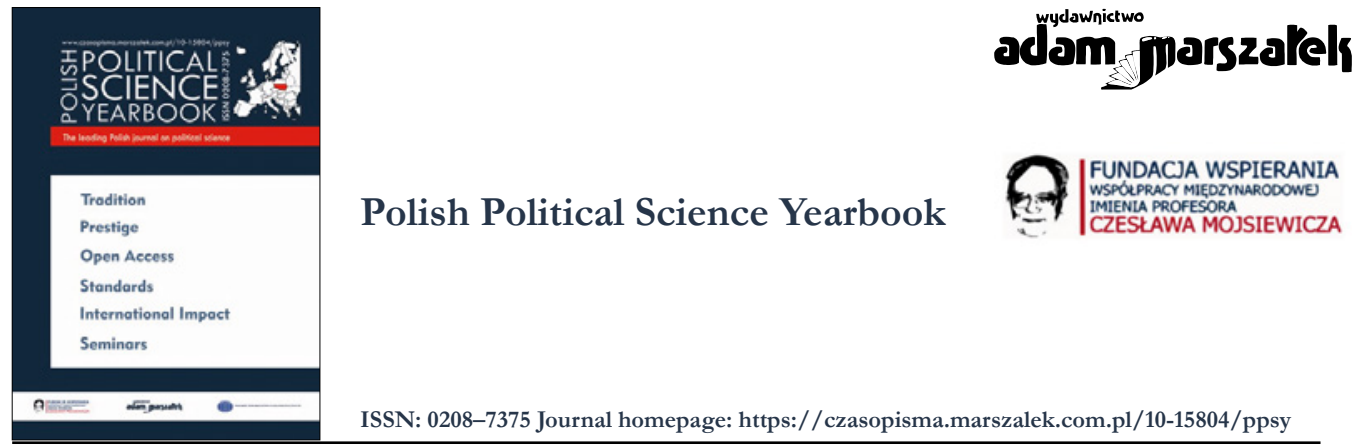

Book Review: Zbigniew Girzyński, Jarosław Kłaczkow, Jan Żaryn (Eds.), Fundamenty Niepodległości. Sejm Ustawodawczy (1919-1922), Toruń 2020, pp. 574

\title{
Lech Wyszczelski
}

ORCID: 0000-0003-2063-4281

To cite this article please include the following information:

- Journal title: Polish Political Science Yearbook

- Volume number: 50

- Year of publication: 2021

- Published ahead-of-print

Example styles:

[APA Style]: Wyszczelski, L. (2021). Book Review: Zbigniew Girzyński, Jarosław Kłaczkow, Jan Żaryn (Eds.), Fundamenty Niepodległości. Sejm Ustawodawczy (1919-1922), Toruń 2020, pp. 574. Polish Political Science Yearbook, 50(issue number), pages. https://doi.org/10.15804/ppsy202106

[Chicago Style]: Lech Wyszczelski, “Book Review: Zbigniew Girzyński, Jarosław Kłaczkow, Jan Żaryn (Eds.), Fundamenty Niepodległości. Sejm Ustawodawczy (1919-1922), Toruń 2020, pp. 574" Polish Political Science Yearbook 50, no. [issue number] (2021).

To link to this article: https://doi.org/10.15804/ppsy202106

Published ahead-of-print

曲 Final submission: 7 June 2021

Published online: 15 June 2021

Printed issue: December 2021

Submit your article to PPSY 


\title{
Lech Wyszczelski
}

War Studies Academy (Poland)

ORCID: 0000-0003-2063-4281

\section{The Legislative Sejm of the RP (1919-1922)}

\author{
Book Review: Zbigniew Girzyński, Jarosław Kłaczkow, Jan Żaryn (Eds.), \\ Fundamenty Niepodleglości. Sejm Ustawodawczy (1919-1922), Toruń 2020, \\ pp. 574.
}

Reclaiming independence for free and sovereign Poland in 1918 and its recently celebrated $100^{\text {th }}$ anniversary have resulted in numerous events directly and indirectly associated with this historic milestone event. One such event is the reviewed book. It regards the functioning of the first Polish parliament in independent Poland - the Legislative Sejm. It was an institution responsible for reconstructing structures for state power, which was a responsibility fulfilled. Eventually, it led to establishing a Constitution and adopting it on March 17, 1921.

The reviewed book presents activities of the first parliament in the Second Republic of Poland. Publishing such a comprehensive study, beautifully edited, with numerous illustrations, and printed in hardcover, would not be possible without sponsorship. In this case, the support was granted by Steczkowski's BGK Foundation and BERM Ltd. The book consists of a topic elaboration made by fourteen authors and a counting 100 pages source elaboration entitled "Meeting Schedule and Main Topics of the Legislative Sejm in 1919-1922" made by Anna Łukaszewska. Furthermore, it includes an introduction and an index of names. In my opinion, the book would benefit from adding an ending and one bibliography for all papers, since it aspires to be a scientific position. The authors are recognized professors and other scholars from renowned Polish universities, including those hired in the Sejm's chancellery. The book was edited by Zbigniew Girzyński, Jarosław Kłaczkow, and Jan Żaryn. I consider it a prominent event for the celebrations of the $100^{\text {th }}$ anniversary of regaining independence by Poland.

The synthetic introduction outlines the book's scope. The following chapters are: Jan Żaryn's “The Legislative Sejm 100 Years Later"; Grzegorz Zackiewicz's “The Main Topics of 
Election Campaign to the Legislative Sejm”; Zbigniew Girzyński’s “Ferdynand Radziwiłł - Senior Marshal of the Sejm”; Grzegorz Kulka’s “The First Legal Act of Free Polish Parliament - Temporal Terms of the Legislative Sejm and Their Further Amendments"; Katarzyna Daraż-Duda's "Presenting the Legislative Sejm of 1919-1922 by National Democratic and Socialist Press - A Comparative Analysis"; Janusz Szczepański’s "Political Groups in the Legislative Sejm toward the Bolshevik Threat in 1920"; Anna Amrochowicz-Gajownik's "Submission - Forced or Necessary? Polish-French Economic Relations on the Forum of the Legislative Sejm”; Katarzyna Witkowska-Chrzczonowicz's "Questionnaires on the 1919 Project of the Constitution of the Republic of Poland and Works on Constitutions in the Second Republic of Poland"; Mateusz Hübner's "State Support Programme for Scholars Working in the Legislative Sejm of Reborn Poland"; "Marek Białokur's "The Visualization of Election to the Legislative Sejm (1919-1922) and Its Main Achievement - the March Constitution - in Contemporary History Education"; Bogusław Pacek's "Actuality of the Council of National Defense's Message of 1920 for the Polish Defense of $21^{\text {st }}$ Century"; Lech Krzyżanowski's "Antoni Matakiewicz - Judge, Social Activist, and Deputy in the Legislative Sejm of the Second Republic of Poland"; Agnieszka Zięba-Dąbrowska’s "Parliamentary and Economic Activity of Adam Cieśla (1883-1944) from Sienna - A Deputy in the Legislative Sejm of 1919-1922"; and Jarosław Maciej Zawadzki's "Heritage of Deputy and Senator Leon Misiołek in the Chancellery of the Sejm's Collections". Besides, the work includes the index of names but lacks an index of geographic locations and other mentioned elements.

What is the general assessment of the quoted papers? Mostly, they are introductory texts, but it does not mean they are useless. In my opinion, Janusz Szczepański’s piece deserves the highest note for studying a vital topic of the Legislative Sejm's attitude toward the Polish-Russian conflict of 1919-1920. The publication is based on source material, including the Archive of the Sejm of the Republic of Poland and the Council of National Defense Protocols. I find the relations between the Legislative Sejm and the Council of National Defense particularly interesting. Szczepański presented them innovatively. Still, though, I see a need for highlighting marshal Józef Piłsudski’s attitude toward the Legislative Sejm and the Council of National Defense. The former was dominated by deputies representing centrist and rightist views, thus against the "Eastern politics" proposed by Piłsudski and his camp, including the promoted "federation idea". The Eastern politics of Piłsudski's camp had many opponents in Poland, especially among the Right concentrated around Roman Dmowski. The Right had the majority in the Legislative Sejm and used it for promoting the idea of incorporation, which made Piłsudski's efforts in the international and domestic arena more challenging; though not always. For example, on February 24, 1920, the Sejm Commission for International Relations outlined rules for peace negotiations with Russia. It adopted a principle to ratify a possible structure by a Russian constituent. However, Bolsheviks dissolved it at the very beginning of 1918, which meant that Poles proposed impossible terms. Piłsudski benefited from the situation. Signing a peace treaty in Riga on March 18, 1921 was, though, an undoubted failure of Piłsudski's Eastern politics. Even 
though he was the head of the state, he could not block its ratification against the shared position of the Legislative Sejm and the government. However, he was taking steps to make its implementation more difficult. These are only selected examples of differences between the political camps of that time.

Another interesting piece is Jan Żaryn's work trying to assess the Legislative Sejm's achievements from the perspective of 100 years. The author considers elections to the Legislative Sejm and its activity the "legitimization of the Polish state in the eyes of Poles and international observers" (p. 15). Also, he makes the Sejm's achievements balance and finds it "extraordinary". The Parliament had sittings for 46 months in a time particularly difficult for Poland. It contributed to establishing the Constitution of March 17, 1921, normalizing domestic law for integration land, and outlining directions for Poland's economic development. Disputes between the head of the state and the Legislative Sejm dominated by centrists and rightists certainly did not help Poland's situation. The author assumes a bold hypothesis - that I share - that "Józef Piłsudski did not fit the corset of democracy while he had full power (also over military forces). He had proponents on the left side of the Sejm, which also did not have the majority. According to rightist deputies, it resulted in a constant threat of coup d'état" (p. 26). Indeed, the May Coup happened on May 12-14, 1926.

I address critical remarks to Bogusław Pacek's paper, trying to find premises behind creating the Council of National Defense that would be useful for the contemporary national defense system. In my opinion, there are not many such similarities. The Council of National Defense was an ad hoc institution established for a period of the biggest threat to the Pole's national existence. It was represented more by the crucial political parties of that time than the military. Moreover, it had supreme power over the head of the state, the Legislative Sejm, the government, and the Chief Command of the Polish Army. It was a collegial body ruled by an asymmetric majority. On July 1, 1920, the Legislative Sejm adopted prime minister Władysław Grabski's proposal and decided on establishing counting nineteenperson Council of National Defense. Then, the power over the council was transferred to the head of the state, marshal Józef Piłsudski. The other Council members were the marshal of the Legislative Sejm, the prime minister, three government and three military deputies, and ten parliamentary deputies (that is why the latter had the majority). The decision was unanimous, which is worth noting. It spoke for the increasing consolidation of society facing the threat of losing independence and sovereignty. All political forces - except for communists - thought that entire state and national potential should be focused on defending the Motherland. Therefore, I am not convinced by the author's thesis about similarities between the Council of National Defense and contemporary solutions implemented in Poland's defense system.

Recalling the introductory character of other elaborations, I will not address them. However, it does not mean that they are worth less than their discussed predecessors.

I consider documentation elaborated by Anna Łukaszewska - Meeting Schedule and Main Topics of the Legislative Sejm in 1919-1922 - a huge achievement of the study. The 
author collected 342 sittings of the Legislative Sejm. Thus, it is a fundamental source and guide for all analysts of this parliament's activity. That is why I acclaim the author's contribution.

Although elections to the Legislative Sejm organized on January 26,1919 included only a part of the territory to which Poland aspired, they legitimized the democratic model of power and were a significant argument for the international position of the reborn country. In time, the personal composition of the parliament has been supplemented by adding deputies from other, new parts of Poland. The Right gained the majority - most deputies were members of the National Democracy. One of the first decisions made by this political body was adopting the so-called Small Constitution that regulated the system of state power. This statement closes the supplementing part of the review.

Does the book cover the activities of the Legislative Sejm fully? Actually, such was the aim of its authors. Pondering on that question, I think it is worth shedding light on incorporating the Vilnius Region into Poland. Lithuanians made unyielding claims to recover Vilnius and adhesive territories (it resulted from action taken by soldiers commanded by gen. Lucjan Żeligowski), and the dispute seemed unresolvable on the international forum. Therefore, Poland took an unconventional step. On January 9, 1922, there were conducted elections to the Vilnius Sejm. 63\% of people entitled with the right to vote took part in them. Lithuanians, Belarussians, and Jews did not use this right. Thus, the Sejm, constituted almost only from Poles, supported the incorporation idea, i.e., joining the Vilnius Region to Poland. The decision was made on its first sitting on February 20,1922. The Sejm appointed twenty representatives who in March 1922 arrived to Warsaw to sign an act merging the Vilnius Region with Poland. It faced difficulties because deputies from Western powers - especially from the Great Britain, France, and Italy - accredited in Warsaw protested against the merge. The Polish government proposed the Legislative Sejm to issue the final statement on the status of Vilnius. In the meantime, the Vilnius Sejm delegation categorically demanded the incorporation. A debate in the Legislative Sejm was heated. Following vast differences, the Polish government resigned from continuing the term. On March 24, 1922, the Legislative Sejm unanimously ratified the act incorporating the Vilnius Region to Poland and extended its personnel of the twenty delegates of the Vilnius Sejm. It is just one example of the first Polish parliament's works.

Summarizing, I assess the reviewed position positively. It enriches studies on the newest history of Poland. Maybe it will interest Western scholars. Definitely, it should be available not only in scientific libraries. In the first place, I recommend it to historians studying the Second Republic of Poland and history students. Politicians also would benefit from reading it. Among the current politicians in power, many historians refer to the discussed period, although apparently, they do not know much about it. Finally, I recommend the book to all other readers, not necessarily historians but countless persons passionate about the interwar period in Poland. 